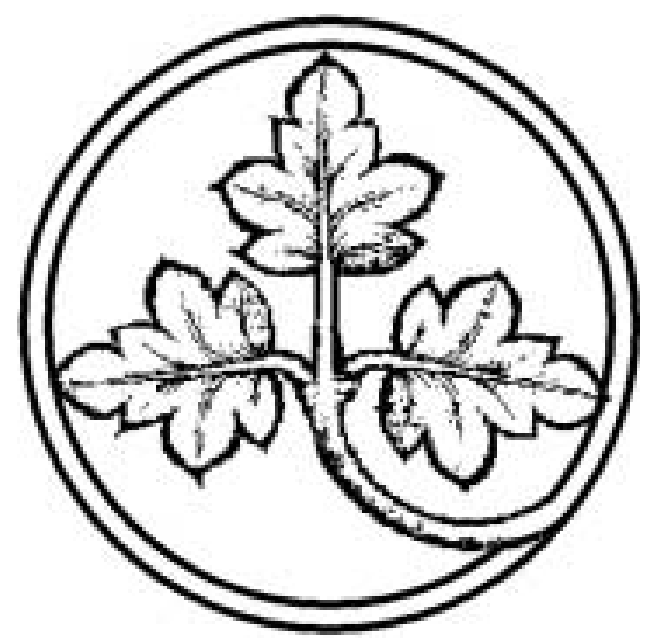

Gemeinschaftsgüter: Recht, Politik und Ökonomie

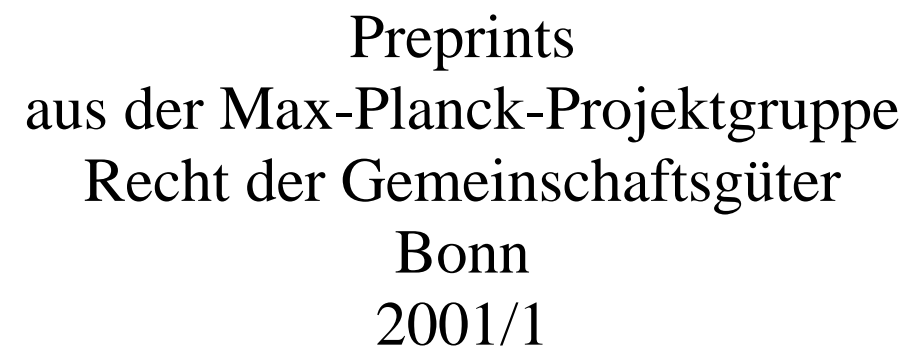

The Politics of Public Services in European Regulation

VOn

Adrienne Héritier 


\title{
The Politics of Public Services in European Regulation
}

\author{
Adrienne Héritier
}

January 2001

(I am grateful for critical comments to Dominik Böllhoff, Tanja A. Börzel, Christoph Engel, Henry Farrell, Christian Geiger, Dieter Kerwer, Leonor Moral Soriano, Jeremy Richardson, and Susanne K. Schmidt.)

Max-Planck-Projektgruppe Recht der Gemeinschaftsgüter, Poppelsdorfer Alle 45, 53115 Bonn

www.mpp-rdg.mpg.de 


\section{Introduction}

Although the goal of market integration has not actually been challenged in recent years, it has nevertheless increasingly come to be considered incomplete and in need of complementary goals which serve the general interest by promoting social cohesion and equality (Bauby, Boual 1997). The debate has been conducted in various areas, such as in the fight against unemployment and poverty and in the provision of public utilities. In the latter case, regarding the provision of energy, water, communication and transport, the debate was sparked by the privatisation of public monopolies and their infrastructure networks, and the deregulation of service provision. The network industries which had traditionally been shielded from competition and were run within national boundaries were dramatically transformed. This change - which in some countries resulted from European legislation - was meant to induce more producer competition, improved productivity, more consumer choice in the supply of network services, and lower prices (Bergman et al. 1998:4). However, it has triggered concerns over the maintenance of general-interest goals in service provision, i.e., over safeguarding the accessibility, equality, continuity, security and affordability of these services after liberalisation. There is a general political consensus that communicating by voice telephony, enjoying a certain degree of mobility, and using energy are basic needs that should be guaranteed and that firms operating in network industries should thus be subject to "public-service" objectives (Bergman et al. 1998:6).

This issue is part of the wider question regarding whether European policy-making is inextricably and systematically biased in favour of market-making policy or negative integration (economic regulation), as opposed to market-correcting policy or positive integration (often social regulation). F.W. Scharpf argues that such a bias exists and is in fact due to the supremacy of European law, the prevalence of the four freedoms and the injunctions of the Commission against distorting competition (Scharpf 1999). This decisionmaking avenue - so the argument goes - is relatively easy to handle and does not run into many decision-making obstacles. By contrast, market-correcting policy arguably has a greater need for consensus because it has to be passed by the Council and, increasingly, by the Parliament. The empirical findings in the sectors under study here, however, partially contradict this claim. There are indeed decisions seeking to correct market outcomes. They show that beyond the powerful forces in favour of competition there are particular institutional mechanisms and strategies which work to the advantage of market-correcting policies in the network services, which after deregulation foster re-regulation benefiting the public interest. These are firstly the shifting of an issue from one arena to another in order to 
make it possible to apply an institutional rule lending more bargaining power to a minority position, and, secondly, the inclusion of an actor with a strong stake in general-interest issues; namely, the European Parliament. Both strategies may be combined.

This essay raises the questions: why and to what extent does a conflict exist between economic liberalisation and general-interest goals in the first place? I will then turn to the role of European policy-making, which aims at striking a balance between the poles of market integration and competition, on the one hand, and the provision of public services, on the other. What are the existing European policies and how do they fare when measured against these two goals? I then focus on the central question of the analysis: how can the pro-generalinterest decisions at the cross-sectoral and sectoral level (in energy, telecommunications and rail) be accounted for in terms of the interaction of the formal political and legal actors involved in shaping the outcomes at the European level? ${ }^{1}$

\section{The economics of regulation: are liberalisation and general-interest services conflicting goals?}

Before liberalisation, network industries were shielded from competition because - from an economic perspective - they were considered to be natural monopolies in which one provider could offer services cheaper than several because of a specific cost structure such as the high start-up investment for service provision required to join the technical network infrastructure and economies of scale. From a political perspective the services provided on the basis of a natural monopoly are considered to be politically and socially desirable, and the access of all customers should be guaranteed. Therefore they should be organised as public monopolies or publicly-licensed private monopolies (Baumol, Panzar and Willig 1988). Liberalisation challenged the economic view that network utilities are natural monopolies, and it introduced the notion of "contestable markets", arguing that while - in view of sinking costs and economies of scale - the network infrastructure should have one owner, the operation of services on the network could be opened up to competition in order to increase the efficiency of service provision (Engel and Knieps 1998). With the abolition of public monopolies and the liberalisation of service operations, the number of firms operating would increase and the

1 I hence focus on the functional dimension of regulation (concerned with the scope and goals of regulation) as shaped during policy formulation, and not on the organizational dimension of the design and architecture of regulatory institutions. For the de facto effects of liberalization on the performance of network industries in rail transport and telecommunications measured against general- interest goals, see Héritier 1998; Héritier and Schmidt 2000. 
ensuing competition would lead to greater productivity, thereby widening consumer choice and lowering prices. In this way liberalisation would promote the general-interest goals of accessibility, equality and affordability. However, this would not occur if market failure led to only one or more firms acquiring market dominance and thus being able to fix prices too high, thereby working against the interests in a universal and affordable service (Bergman et al.

1998:116). ${ }^{2}$ A customer for whom the access charge (which need not be above cost) is too high, does not have access to services. This may be the case for customers living in remote areas with low population density where there are no economies of scale. Network industries, however, are politically obliged to provide goods with "merit good" characteristics. In other words, it is a political decision that certain goods, such as access to domestic water, electricity and voice telephony services, must be provided regardless of whether this runs counter to the service operator's efficient pricing policy. Therefore, from the perspective of the political decision-maker committed to citizens'/voters' general-interest goals, political marketcorrecting regulation is needed in order to offset the unwelcome effects of market processes; setting a price limit on the provision of a specific infrastructure service provides one typical example of such regulation.

Hence, it can generally be argued that liberalisation can facilitate the realisation of servicepublic goals in specific circumstances by the price cuts and the corresponding wider accessibility resulting from competition. At the same time, however, it gives rise to a two-fold need for re-regulation: firstly, in order to make markets work and to prevent market dominance from becoming concentrated in the hands of a few actors, and, secondly, to correct the outcome of market processes so that social and political goals may be met. How do European policies seek to strike a balance between the two goals of market liberalisation, on the one hand, and market-correction to promote general-interest services in the utilities, on the other?

2 Another consequence which interferes with the principle of universal service may arise where there are positive network externalities. If a person cannot join a network because of a relatively high access price (which need not be above cost), the other network members are denied positive network externalities (Bergman et al. 1998:117). 


\section{European legislation which promotes general-interest services}

Since the 1980s Community policy has been dominated by the goals of liberalisation. In recent years, however, there has been an increasing emphasis on policies which emphasize goals of social cohesion. The call for maintaining universal service reflects this new orientation (Scott 1995). Policy-making which is aimed at strengthening the promotion of general-interest services in the utilities is based on Art. 86.2 (ex 90.2) of the Treaty of Rome, which allows member states to grant special rights and obligations to particular undertakings. Art. 86.2 (ex 90.2) specifies that monopolies and services in the general economic interest only have to comply with competition rules if they do not prevent companies from performing the tasks assigned to them. Art. 86.3 (ex 90.3) entrusts the Commission of the European Community with the implementation of these rules, and allows the use of directives and decisions which do not need to be corroborated by the Council of Ministers.

Several rulings of the European Court of Justice have upheld the practice of establishing limits on competition for certain services of general economic interest. In the Corbeau ruling of 1993, for example, the ECJ acknowledged that Art. 86.2 (ex 90.2) can legitimise such restrictions. In the Almelo ruling of 1994 the Court confirmed the direct effect of Art. 86.2 (ex 90.2) and specified that any assessment of restrictions on competition must take into account the economic conditions in which the company finds itself and the environmentalprotection regulations to which it is subject. In another decision in 1997, on the matter of financing France Poste, the ECJ incorporated the concept of general economic interests into the ruling. It stated that public services provided by the post office must include the collection, transport and distribution of mail for all users of the territory of a member state at uniform tariffs and similar qualitative conditions, irrespective of the particular situation and the profitability of each individual operation. The fiscal advantages granted to public-service enterprises are not considered to be illegal state aid if they do not go beyond the constraints resulting from the particular public-service mission.

The Commission Communication of 1996 also reflects the increasing importance attached to general-interest services ${ }^{3}$. Here, for the first time, the Commission explicitly recognises their importance and presents them as key elements in the European model of society. "Solidarity

3 The Commission defines services of general interest as "market and non-market services which the public authorities class as being of general interest and subject to specific public service obligations". Services of general economic interest as used in Art. 86.3 (formerly 90.3) of the Treaty are defined somewhat more narrowly as "market services which the member states subject to specific public service obligations, such as transport networks, energy and communications".

"Universal services", a concept developed in Community bodies, are "a set of general interest requirements which should be satisfied by operators of telecommunications and postal services, for example, throughout the Community. The object of the resulting obligations is to make sure that everyone has access to certain 
and equal treatment within an open and dynamic market economy are fundamental European Community objectives; objectives which are furthered by services as social rights that make an important contribution to economic and social cohesion. This is why general interest services are at the heart of the European model of society" (European Commission Communication 1996:1). The objective is to ensure a mutually-beneficial interplay between the requirements of a single market and free competition, free movement, and economic performance and dynamism, on the one hand, and general-interest objectives, on the other. The Commission considers this to be a difficult balancing act since "the goal posts are constantly moving: the single market is continuing to expand and public services, far from fixed, are having to adapt to new requirements" (Commission Communication 1996:3).

As a result of the Intergovernmental Conference for the Amsterdam Treaty, a new Art. 16 (ex 7D) was introduced, which stresses the role of general-economic-interest services in the Community values and the role they play in advancing social cohesion in the European Union. This article still upholds the primacy of competition rules in principle, but for the first time it explicitly introduces general-economic-interest goals as European values; it thus contrasts with the previous situation, under the Maastricht Treaty of 1992 and the Single Market Programme of 1987, when general-interest services were primarily regarded as an obstacle to market integration. How did this change in policy and law-making come about? It will be seen at the empirical cross-sectoral level that the change reflected in the Amsterdam Treaty was achieved after a lengthy political battle in the European arena, spearheaded by France. But first a general explanation of the political dynamics leading to general-interest outcomes in the interaction between European actors will be presented, which will then be applied to utility policies.

\section{$4 \quad$ Why European policies which promote general-interest services? The political process: General propositions}

The outcomes of the European decision-making process are explained on the basis of a reconstruction of the constellations of interest and the strategies employed by formal key actors in the context of a specific, enabling and restricting European institutional setting, that is, an actor-centred institutionalist approach (Mayntz, Scharpf 1995). The analysis of the European formal decision process is viewed against the background of the national and European political dynamic built up under the impression of domestic socio-political conflicts.

essential services of high quality at prices they can afford" (European Commission Communication 1996:2). 
Informal political and social actors are taken into account both in respect to how they pressure the formal political and legal actors to put public-interest issues on the decisionmaking agenda. However, the main explanation focuses on the formal decision-making process and its outcomes.

The two basic institutional conditions for interaction in European decision-making are: a) the decision-making rules that are applied; and b) multi-level and multi-arena government.

a) The decision-making rules that may come to bear in shaping European policy outcomes in the three sectors under study are: firstly, the unanimity rule, evoked, on the one hand, when the question of general-interest services is discussed at the IGC level during Treaty revisions, and, on the other, in decision-making cases in transport policy where, as a matter of convention, unanimity is evoked if a member state requests it. Secondly, and by contrast, the Qualified Majority Rule may be applied when the utility issue in question is dealt with as a market integration issue. Finally, the competition route allows for a relatively secluded decision-making process involving only the Commission and the ECJ in cases in which the Commission decides to invoke Art. 86.3 (ex 90.3) and to issue a directive, and in cases when the Commission decides to use an infringement procedure against an individual member state. Depending on which route is chosen - the Treaty Revision (unanimity) path, the internal market (qualified majority) path or the competition path - a different number of formal actors are involved and power is distributed differently.

\section{Table 1}

Decision-Making Rules

\begin{tabular}{|l|l|}
\hline Unanimity Rule & $\begin{array}{l}\text { - Intergovernmental Conferences } \\
\text { - Transport Policy }\end{array}$ \\
\hline Qualified Majority Rule & - Market-Integration Issues \\
\hline $\begin{array}{l}\text { Commission Directive (Art. 86.3) } \\
\text { Commission Decision } \\
\text { Infringement Procedure } \\
\text { (+ECJ Ruling) }\end{array}$ & - Competition Issues \\
\hline
\end{tabular}


b) The second aspect of the institutional context, multi-level and multi-arena government, involves the use that actors at the national and sub-national level make of actors at the European level to achieve their goals, and vice versa. They do so by forming alliances with one another vertically across levels and horizontally across arenas, and by using access to additional decision-making arenas - not merely those in the domestic context (such as the European Court) - to press for a formal decision which may benefit their cause.

The two institutional aspects, decision-making rules and multi-level/arena government, may be linked. Thus, moving from one arena to another may involve the use of a different decision-making rule, which is more or less restrictive. Thus, shifting an issue from the sectoral-Council arena to the IGC arena opens up new opportunities. For one thing, the unanimity rule that is applied at the IGC level enhances the bargaining weight of an individual actor while at the same time increasing the number of veto-positions. However, the scope of negotiable issues is also wider at the IGC level, hence the possibilities for striking a deal are expanded.

Within these varying institutional contexts, the following formal actors play an important formal role in the decision-making process: the Commission, the Council, the Parliament and the Court of Justice. Prevalent preferences are attributed to them on the basis of the empirical evidence of past behaviour in the sectors under scrutiny. Their formal institutional resources are defined by the Treaties and the decision-making rule that is applied:

In the past the Commission has shown a clear preference for a policy of market liberalisation in the utilities. Its most important institutional resources in the policy-making process are the right to propose European legislation as well as to oppose a proposal in question. Another important institutional resource is the right to decide, under Art. 86.3 (ex 90.3) how to implement Art. 86.2 (ex 90.2). This article deals with special undertakings, and the Commission has to mediate between public enterprises and the competition rules of the Treaty. The exceptions to the competition rules can be defined by the Commission and the Court without reference to the Council and the Parliament. Even if the Commission does not invoke Art. 86.3 (ex 90.3), it still can threaten to do so and thereby influence the decisionmaking process. This power is enhanced by the Commission's general powers of rule making, investigation and enforcement in competition and state-aid policy, all of which are subject to review solely by the ECJ. What is important is that the Commission's institutional interest to act autonomously is best realised in this area (Schmidt 1998:301) and is most easily expanded in the area of competition policy ${ }^{4}$.

4 However, what makes this tendency less clear cut is that the sector-specific interest represented by another Directorate General (DG) may counteract these endeavours and in fact make it more difficult for the 
The European Parliament has a record of favouring policies which foster general-interest services. This is not surprising in view of its function, which is based on the fact that its members represent constituencies of millions of utility customers/voters who depend on the availability of public services in their everyday lives. The Parliament has upheld public services in sectoral legislation on network activities, on electricity, as well as gas, railway and airtransport networks, telecommunications and postal services. It also issued various general statements of its position to that effect in 1994, 1995, 1996 and 1997 (EP Fact Sheets 1.6.1999, p.4). As regards institutional resources, if the co-decision rule is applied in policymaking matters, it has the right to veto proposals on European legislation.

The substantive preferences of the Council of Ministers are diverse, depending on the different policy objectives of the individual member-state governments and the coalitions formed during negotiations. The preferences of the large member-state governments with respect to utility regulation are more easily defined: while Great Britain - and to some extent the Netherlands - have pursued a clear strategy of liberalisation and rely on the market to increase efficiency and consumer choice, France, Belgium, Italy, and Spain have taken the opposite position, seeking to maintain public monopolies and a public-service tradition in most sectors. Germany has taken up a position in the middle-ground.

Since the Council is the key legislative body in the overall decision-making process, its institutional resource consists in the veto power vis-à-vis the other participants. Of course, within the Council, the influence of the individual country varies according to the decision rule applied: the Qualified Majority Rule creates the need to form coalitions, whereas the unanimity rule puts each national government a position to veto.

The European Court of Justice assumes the role of a latent player in the political game, as it does not directly and explicitly take part in the policy-making process. Its function - at least in theory - is to be impartial to policy preferences, and, instead, to interpret cases which are brought to it in accordance with the principles of the Treaty of Rome, existing legislation and precedent rulings. However, it is a latent player in policy making in so far as it is used as a resource by other players or put in game theoretical terms, actors engage in backwardinduction as to how a court ruling - given precedent rulings- might affect their bargaining position more or less favourably. This in turn influences the path of action chosen by the players. If appealed to in a case, the Court starts to play an explicit role in the policy-making process - although it considers it to be a non-political one. Its institutional resource consists of the power of veto vis-à-vis existing or proposed legislation.

Commission to pursue the goal of liberalisation (Schmidt 1998). 
Interestingly, in recent years the Court has reconsidered its role with respect to judicial activism in utility policy making. It has emphasised the need for deciding at a general political policy-making level, that is, at the Commission, Council and parliamentary level, and it warns the Commission against making overly-extensive use of single-issue- (infringement) procedures subject to Court rulings (Schmidt 1998:263). It even stresses the danger of being instrumentalised by the Commission. Thus it is argued that questions of proportionality, in which legitimate member-state goals of welfare, culture and health are weighed against free trade values, constitute political decisions on societal values, and should not be decided by the Court by means of individual judgements, but by the Council or the Commission (Edward and Hoskins 1995:169). If the Court continues to view its role in such terms, the possibilities of using it and its legal resources as a coalition partner in the policy-making process will be more restricted.

\section{Table 2}

Preferences of Formal Institutional Actors

\begin{tabular}{|c|l|l|}
\hline Commission & $\begin{array}{l}\text { Substantive: } \\
\text { Institutional: }\end{array}$ & $\begin{array}{l}\text { Market Liberalization } \\
\text { Competition Route }\end{array}$ \\
\hline European Parliament & $\begin{array}{l}\text { Substantive: } \\
\text { Institutional: }\end{array}$ & $\begin{array}{l}\text { General Interest Services } \\
\text { Common Market Route }\end{array}$ \\
\hline Council of Ministers & $\begin{array}{l}\text { Substantive: } \\
\text { Institutional: }\end{array}$ & $\begin{array}{l}\text { Dependent on Dominant Coalition } \\
\text { Common Market Route }\end{array}$ \\
\hline
\end{tabular}

Based on the preferences described above, and against the background of the two contextual institutional aspects, the following propositions are put forward, which - I maintain - account for policy outcomes favourable to public-service goals at the European level.

At the cross-sectoral, decision-making level we observe a double dynamic of multi-level and multi-arena policy making:

- If a member state brings a general interest issue to the supranational sectoral level (multi-

level government dynamic),

- shifts the issue from a more limited (sectoral) to a broader (IGC) arena with a wider scope of decision-making (multi-arena dynamic),

- and seeks an alliance with the EP to advance general interest goals, the chances of realising the general-interest policy goal increase. 
At the sectoral level I propose that:

- General-interest goals are more likely to be pursued if the internal market decision route (Art. 95 (ex 100a)) is chosen and the European Parliament takes part in the decisionmaking process under Art. 251 (ex 189b) (co-decision rule).

- If, by contrast, the competition route is chosen under Art. 86.3 (ex 90.3), the realisation of public-interest goals is more likely.

- The Commission uses infringement procedures in order to increase individual member states' willingness to support liberalisation policies at the Council level.

The decision as to which path - i.e., the treaty revision path, the internal market path or the competition path - is chosen, depends both on:

- whether member state governments support an issue to be put onto the IGC agenda, and

- whether member-state governments engage in substantive and institutional resistance vis-à-vis the use of Art. 86.3 (ex 90.3) by the Commission.

With respect to the Court, whose legal resources tend to be exploited by all actors it is claimed that

- a political actor who can credibly claim the support of the Court by referring to precedents favouring general-interest services is more likely to achieve his or her policy goals. 


\section{General propositions in the light of the empirical political process: the cross-sectoral level}

In trying to answer the question regarding how general-interest services, as a cross-sectoral objective of European policy making, came to be incorporated into the Amsterdam Treaty, the role of France, as the promoter of service-public interests ${ }^{5}$ and as a player in the two-level and cross-arena game, is of paramount importance. The public service debate is primarily being conducted in France, Belgium, Spain and Italy, whereas there is no corresponding notion of a "public service" in countries such as Great Britain, Germany or the Netherlands (Schmidt 1998:227) ${ }^{6}$. In brief, in the political decision-making process, the domestic conflict which evolved in France around the issue of social cohesion, in which the public services play a crucial role, spilled over to the European level in the course of the liberalisation process. In spite of only constituting a strong minority position at this level, France, in coalition with the European Parliament - which had increased its sway under the co-decision rule -, succeeded in inducing the Commission, which had hitherto single-mindedly pushed liberalisation (Belloubet-Frier 1994:273), to issue its Communication supporting generalinterest services. Simultaneously, various Court rulings in favour of general-interest services initiated by companies set up as legal monopolies provided support for the French claims. The general-interest services discussion was subsequently shifted to the IGC arena. The upshot was that in the Amsterdam Treaty general-interest services were explicitly stated to be an objective of European policies.

The French notion of "public service" developed as a counterpart to "puissance publique" in French administrative law and at the end of the $19^{\text {th }}$ century gave rise to an extended debate in the discipline. The advocates of "puissance publique" conceived of the state as a sovereign power dealing with its subordinate subjects by means of command and control and other rules. The adherents of the "public-service school" conceived of administrative action less in terms of super- and sub-ordination. Rather - under the impact of economic liberalism and the beginnings of social benefits bestowed by the state - they viewed the state as delivering services and benefits to citizens. Today public service in France is defined as an activity which is deployed by a public enterprise in the general interest. However, the government can also charge private actors to perform these activities (Le Nestour, Zinow 1994:129/30). It is strongly influenced by the "esprit de corps" of the engineering schools and their centralist and technocratic views of the utilities (Schmidt 1998:227).

6 Nonetheless, there are some forms of public-service principles in Great Britain too, such as universal service in telecommunications and non-discrimination within the UK utilities law (Prosser 1994:16). Even though the Citizens' Charter exercise has its limitations, it can be seen as "the germ of an idea that access to public services is something to which citizens have a legitimate right" (Prosser 1994:17). In Germany the notion of Daseins vorsorge (Forsthoff 1968). 


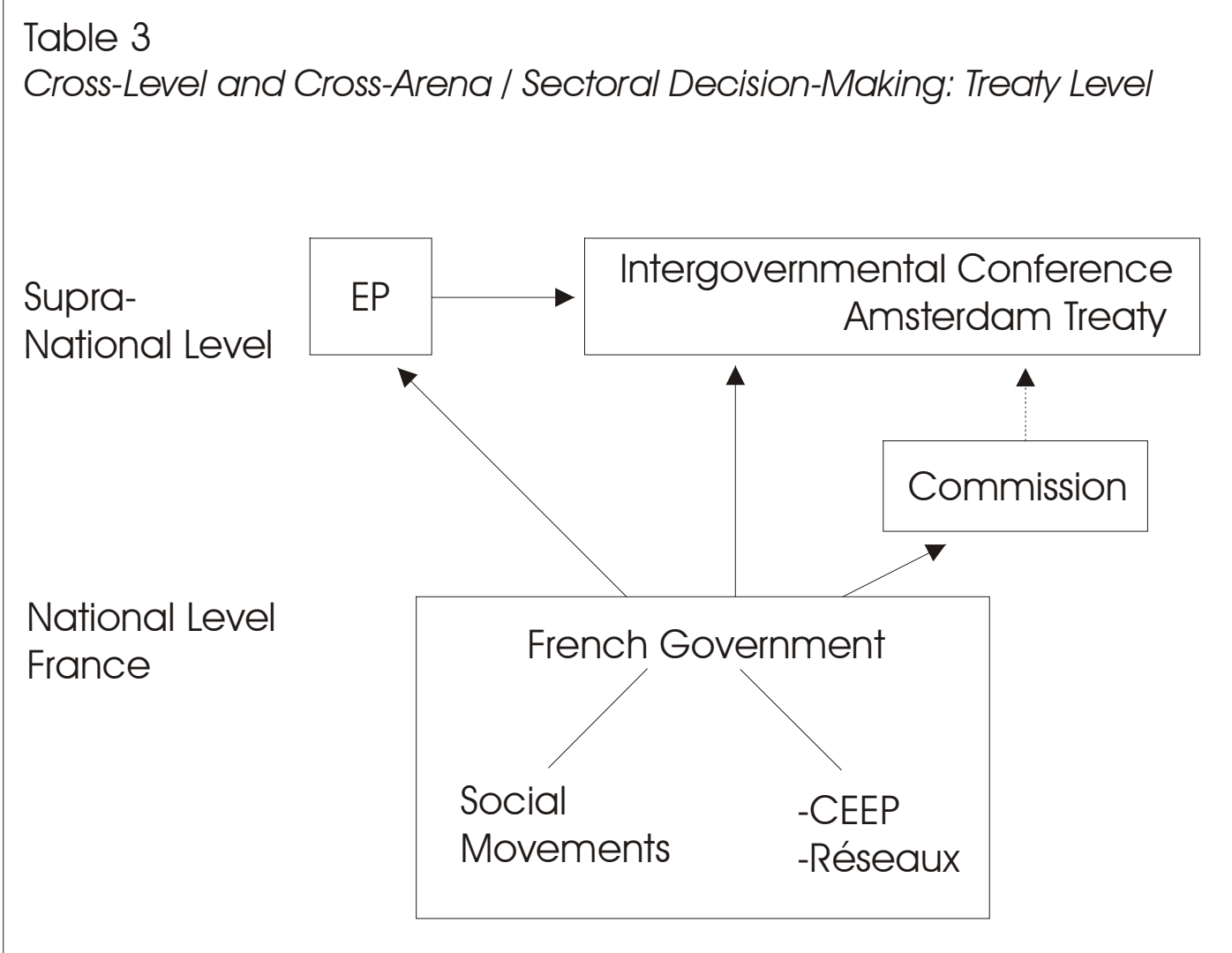

A more detailed analysis of the process shows that the dynamics of the two-level political process unfolded as follows: at first, when activities were still focussed on French domestic politics - i.e., in the early 90 s - France only slowly responded to the challenge which the liberalisation of public utilities posed to its tradition of public service. Only individual actors such as the utility operators and the unions - reacted, signalling their protest to the European liberalisation impetus. A general view and policy concept was developed by the French dominated Centre Européen des Entreprises à Participation Publique (CEEP), defending the interests of public corporations and providing a counter-balance to those interest groups, such as the International Telecommunications Users Group (INTUG), which strongly supported liberalisation (Scott 1995:211). A critical stance was also taken by X-Europe Réseaux, the association of the former students of the Polytechnique, a higher education institution, which was concerned about the professional status of the French polytechnicians in the French network services (Bauby, Boual 1997:318). They created a public-service interest association, "Réseau Service Public", with the aim of systematically tying the future of public services to the construction of Europe as a polity, and re-establishing the legitimacy of the public services vis-à-vis liberal claims. (Bauby, Boual 1997). The réseau then proceeded to develop a crosssectoral network of support for public services, first at the national level, which included a variety of public and private actors such as politicians and administrators, utility operators, unions, consumer associations and academics. Several conferences were organised where the 
European challenge to public-interest services was discussed and supporters rallied to defend them (Bauby, Boual 1993, 1994). The social movements in favour of more social cohesion in Europe in 1995, and the strikes of the transport workers, which enjoyed considerable popular support, as well as the demonstrations against unemployment, all this increased the pressure of such domestic conflicts and aided the endeavours to influence the European utility policy.

In a second stage these activities were systematically carried over to the European level, targeted at the culprit, as it were. As a result of interministerial consultation, a memorandum was delivered to the Commission asking for a European Charter. The President of the Commission at that time, Jacques Delors, asked the CEEP to submit a draft for such a charter. "Though the Commission has shown some muted enthusiasm for such a Charter, it has fallen to the interest group which represents public enterprises in the member states, the CEEP, to develop its principles" (Scott 1995:211). At this point links were established with the European Parliament, where a working group, " public service ", was instituted. Simultaneously, the group Réseaux 2010 at the Commissariat du Plan was established, and the Initiative for Public Services in Europe was launched (Bauby, Boual 1997:321). In 1994 Réseaux Services organised the first European forum in Brussels which brought together diverse actors concerned with public services. As a result, the "European Liaison Committee on General Interest Services", the secretariat headed by the French "Réseaux Services Publics" mentioned above, was formed. At the Amsterdam conference the Liaison Committee, in co-operation with the European Parliament, now set out to influence the revision of the Treaty in matters of public services by putting together an alliance of diverse European actors in order to counter-balance the competition-oriented logic of the Treaty with general-interest logic. In deploying and master-minding the political strategy, France was circumspect enough not to impose the "French model" of "service public" and "to be too franco-français" (Bauby, Boual 1997:323), pursuing a two-pronged strategy instead. It simultaneously criticised and called for a reform of its own public services while pressing for a European concept of general-interest services.

The objectives pursued were to be set out in a European Charter establishing public services as fundamental rights under Art. 2 of the Treaty of Rome. General-interest goals were to be incorporated into the Treaty in the context of Union citizenship, consumer protection, the Trans-European Networks, the competitiveness of industry, economic and social cohesion, and environmental protection. Art. 86 (ex 90) was to be revised to ensure that competition and general-interest goals were henceforth treated equally as Community goals (Bauby, Boual 1997:325). At an institutional level, a systematic evaluation of the performance of public services was to be introduced, subjecting operators and regulators to the scrutiny of 
an independent Office of Evaluation. This would apply evaluation criteria in a "pluralist confrontation" of different actors, made possible by its specific composition of regulators, operators, different types of consumers, personnel, unions and representatives of civil society. Only in this way - so the argument went - could the notorious asymmetry of information between regulators and private regulatees be overcome (Bauby, Boual 1997:325).

A first success was achieved in 1996 when the European Parliament voted in favour of a resolution that the European Community should not only be oriented towards the creation of a single market but also towards the pursuit of general-interest goals, to be included in Art. 86.3 (ex 90.3) and Art. 95 (ex 100a) of the European Community Treaty and in a modified Art. B of the European Union Treaty (Schmidt 1998:262). Another achievement was the explicit recognition of the importance of general-interest services in the Commission's Communication of 1996. This Communication was developed in co-operation with the Liaison Committee. It stresses the importance of all sectoral general-interest services as key elements in the European model of society. Sector by sector, the liberalisation measures are legitimised, with due regard to the link between the new market dynamics and the imperatives of general-interest services ${ }^{7}$. As for the revision of Treaty, the Commission advocates that the conference insert a reference to general-interest goals by adding a new paragraph on Community goals to Art. 3 to the effect that the Community should contribute to the promotion of services of general interest.

The response of the member states to the Commission Communication in the Intergovernmental Conference differed greatly. Whereas one fraction, composed of France, Belgium, and to a lesser extent, Spain and Italy, proffered strong support for general-interest services, Great Britain expressed support for deregulation, and Sweden, the Netherlands and Germany pursued a mixed or divided strategy. The French and Belgian governments went furthest by proposing revisions to the Treaty, i.e., the specification of Art. 86 (ex 90), in order to safeguard general-economic-interest services. However, only the French Parliament obliged its government to support the modification of Art. 86 (ex 90) during the IGC negotiations. At the same time, there were fears that defining European public services at too low of a level of consensus (Le Monde 1.6.1995 cited in Schmidt 1998:231) would be detrimental to the notion as such. Belgium also asked for public services to be guaranteed in terms of individual rights. This was supported by Italy and Spain, which stressed the link between public service and employment. Great Britain clearly opposed this and pressed for more far-reaching deregulation at domestic and European levels. Finally, there were the countries which pursued

It also explicitly stresses that the organisational form for providing these services may vary: the services can be organised in a legal monopoly or in a competitive situation by private companies, by public bodies or public-private partnerships. 
a divided strategy, namely Sweden, the Netherlands and Germany. They would not come out clearly against or in favour of deregulation in the Council of Ministers. Instead, they hoped to shift the problem of public services and their necessary reform from the domestic to the European level, making Europe a scapegoat, as it were. At home they were reluctant to take an explicit pro-deregulation stance (Dury 1996:22), playing a two-level game, attempting to avoid domestic political costs by shifting the blame to Europe.

A majority in the European Parliament was in favour of incorporating principles of general-interest services into the Treaty. The European Socialist Group in particular pressed for these principles and for the introduction of a Citizens' Charter. The European People's Party sought to widen general-economic-interest services by adding universal services and guaranteeing the quality of certain services (Dury 1996:23). Debates in the Parliament also explicitly referred to its institutional interests. It was very critical of the Commission applying decisions under Art. 86.3 (ex 90.3), thereby by-passing the Council and the Parliament, and it sought to ensure a broader and more open democratic decision-making process in utility matters. The fact that Art. 251 (ex 189b) of the Maastricht Treaty gives the European Parliament a role in decision-making has resulted in political actors becoming more widely involved in the decision-making process on utilities, which has brought about a "gradual cultural change under which utilities law and policy is increasingly seen as a political rather than a technical area, and therefore an area in which political debate is possible (Judge et. al. 1994)" (Scott 1995:211). As an outcome of the decision-making process of the Intergovernmental Conference, a new Article 16 (ex 7d) was enacted in the Treaty of Amsterdam. "Without prejudice to Art. 73, 86 and 87, and given the place occupied by services of general economic interests in the shared values of the Union as well as their role in promoting social and territorial cohesion, the Community and the member states, each within their respective powers and within the scope of application of this Treaty, shall take care that such services operate on the basis of principles and conditions which enable them to fulfil their missions" (Consolidated version of the Treaty on European Union, p. 48).

Thus France, pressed by internal domestic conflicts, successfully played a two-level and two-arena game, shifting the debate around general-interest services first from the national to the European level, and there in the official decision-making process from the sectoralCouncil arena to the cross-sectoral Intergovernmental Conference arena. As a result, the general-interest-services debate gained force and salience at the cross-sectoral level.

However, a new orientation towards social regulation and general-interest services occurred not only at the cross-sectoral but also at the sectoral level. 


\section{Sectors}

\subsection{Telecommunications}

Extensive technological and economic changes had been transforming telecommunications. International competition and technological modernisation called into question both the existing public monopolies and the coalitions which supported the existing regulatory institutional arrangement (Thatcher 1999:3). In Europe, Britain was the first to change its regulations, while in many other European countries, such as France and Germany, the old institutional structures persisted. Following a Green Paper in 1987, a number of European regulatory measures (notably in the form of Directives) were issued on competition issues, prohibiting member states from maintaining legal monopolies over supply in the market segments of terminals, advanced services, satellites and mobile communications. In the mid1990s European legislation also targeted the monopolies at the core of the sector - voice telephony and the building and operation of telecommunications networks - until, by 1998, it had extended across the entire sector (Thatcher 1999:4). The second set of provisions introduced re-regulation, specifying the conditions of supply. They are to secure fair and effective competition as well as universal service, together with the mechanisms that member states could use to fund universal service obligations (Thatcher 1999:4).

Viewing the empirical process of liberalisation and re-regulation as analysed in the literature (Schmidt 1998; Thatcher 1999) in light of my sectoral hypotheses regarding generalinterest services, it appears that the Commission has indeed used the competition route to a considerable extent to advance the process of liberalisation and has been supported by the Court in these endeavours. The Commission used Art. 86.3 (ex 90.3) to issue directives to all member states, and it thereby avoided the need for formal Council approval in order to realise its goal of introducing competition. However, each of these directives has subsequently been challenged before the Court by one or more member states (Schmidt 1998; Scott 1995), particularly on institutional grounds, since member-state governments have objected to the use of Commission directives which by-pass the Council, while in principle they have supported the substance of the directive. The Court, in its turn, upheld the Commission's view that, under Article 90.3, it had a right to make rules in the form of directives to clarify the obligations of the member states (Scott 1995:209).

In her empirical analysis of the process, Susanne Schmidt emphasised that in order for the Commission to be able to use Art. 86.3 (ex 90.3) it had to prepare the ground thoroughly in advance. By publishing its Green Paper, it was able to mobilise support in a sector 
characterised by rapid change and uncertainty. Among member states, Britain was most supportive because it wanted to prevent the other countries from maintaining their monopolies (Thatcher 1999:5). The group of countries in favour of a common European telecommunications policy increased in size, and so did the support of network operators, the PT'Ts. In frequent consultations between Commission and Council, an agreement was reached on how to use Art. 86.3 (ex 90.3), which guarantees that member-state interests are included from the outset. Hence, in subsequent directive decisions the Commission made sure that it secured the prior support of the Council (Schmidt 1998:398).

What emerged empirically, beyond what was expected, was that by means of Art. 86.3 (ex 90.3) - this act of unilateral liberalisation - in some Council directives the Commission was able to put member states under pressure to re-regulate. A link between the two routes was established which gave pro-liberalisers the edge in policy making: since liberalisation goals had already been established through Art. 86.3 (ex 90.3), pro-liberalisers had a more favourable position in negotiations over re-regulation (Schmidt 1998:311), a condition which would render the enactment of legislation in favour of general-interest services more difficult. It was claimed that the European Parliament should also be opposed to the Commission's use of Art. 86.3 (ex 90.3) for institutional reasons. This is only partially confirmed by the evidence. Initially the EP was very critical of the usage. However, once the ECJ had upheld the use, it started treating Commission directives like other directives, commenting on them, while not objecting to the procedure as such (Schmidt 1998). At the cross-sectoral level, by contrast, the Parliament has generally been very critical of the Commission in using Art. 86.3 (ex 90.3).

The competition instrument of infringement in individual cases was applied to prepare the basis for a Council directive. In the event of the Court's support of the infringement procedure against a member state, this state - in view of its liberalised market - had a concrete interest in other member states following suit and supporting a Council policy in favour of liberalisation (Schmidt 1998:314). Hence infringement procedures were skilfully used by the Commission to create individual member states' stakes in a general decision in favour of market liberalisation in the Council.

The momentum of liberalisation was turned in favour of general-interest services by bringing the European Parliament into play and using the market integration route. The Commission itself deliberately used the development of universal-service principles as a means of achieving the widest possible support for the policies of liberalisation in the Parliament, which in 1993 and 1994 adopted various resolutions to uphold public services in telecommunications (EP Fact Sheet 1.6.1999, p.4). Setting standards above current national minima helped gain the support of the Parliament, which is concerned about the social effects 
of liberalisation. In 1993 the Commission adopted a Communication on universal service in telecommunications, defining minimum standards such as the rights to have a telephone connected, to shorten installation and repair times, to specify dispute resolution mechanisms and to have access to new services in the future (Scott 1995: 213). The Directive on the Application of Open Network Provision to Voice Telephony of 1995 and 1998 reflects these principles, as does the "Full Competition" Directive of 1996 and the ONP Interconnection of 1997 (Hart 1998:841).

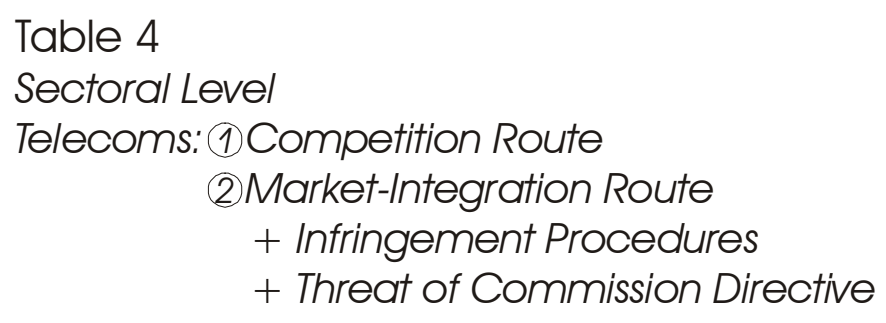

(1)

Supra-

National Level

National Level

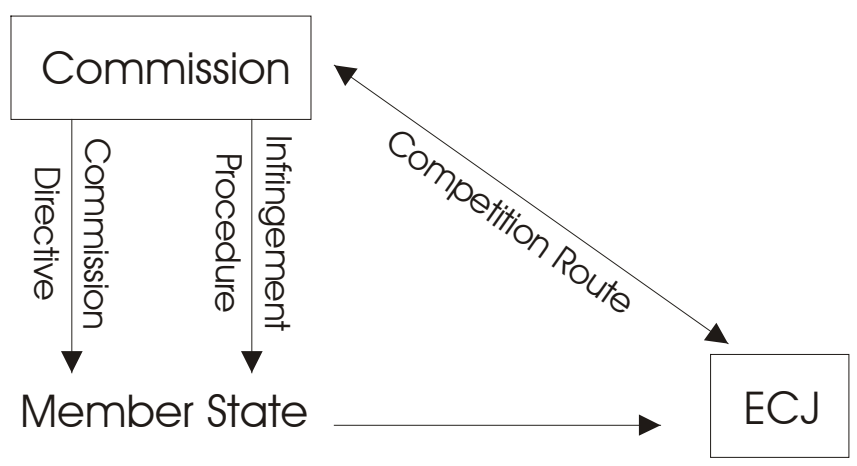

(2)

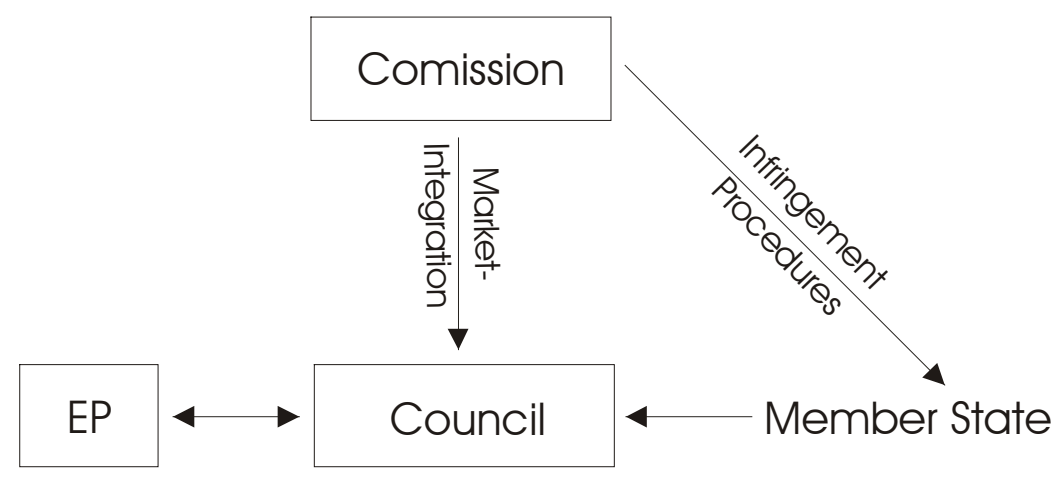




\subsection{Energy}

Like other network utilities, electricity typically has long-term, specific assets which require a high start-up investment, an integrated network (the grid) and high co-ordination requirements (Eberlein 1999; Schmidt 1998). It is also characterised by fluctuating demand and the fact that it cannot be stored, which make it difficult to offer a continuous sufficient capacity. Nor can a substitute be found which increases the supply security problems. For these reasons the sector has traditionally been regarded as a natural monopoly, which is best organised as a vertically-integrated system controlled by the government and not subject to competition. In the course of world-wide liberalisation in the 1980s and 90s, however, the sector underwent a radical transformation (Eberlein 1999:14; Schmidt 1998; Eising 2000). The objective was to increase efficiency and to reduce costs by separating the operation of the infrastructure, i.e., the installation and management of transmission and distribution networks in the generation and supply of electricity.

In Europe the agenda of market reforms faced a heterogeneous landscape of national electricity-management systems (McGowan 1996; Matlary 1996). Basically there were two different types of national electricity systems: vertically-integrated national monopolies such as existed in Britain and France, on the one hand, and decentralised fragmented systems such as in Germany, on the other with its complex system of public and private ownership on different territorial levels as regional monopolies (Eberlein 1999:15; Schmidt 1998:185).

The variety of national backgrounds and the diversity of policy goals resulting from them posed many hurdles, which the European decision-making process had to overcome in its attempts to institute a Common Energy Policy, starting in 1988 with the Commission's report on the "Internal Market for Energy" (Commission 1988). The first attempt at liberalisation provoked considerable opposition from both sectoral and governmental actors (Schmidt 1998; Eising 2000). Anticipating further massive opposition, the Commission decided not to act under Art. 86.3 (90.3), but to choose instead the market-integration avenue when it proposed its first draft directive in 1992. The entire time that the Commission was pursuing this decision route, it was also threatening to bring import and export monopolies before the Court of Justice (Schmidt 1998; Eising 2000). The draft directive met with stiff opposition in the Council and the Parliament, the latter adopting a resolution in favour of public services in electricity and gas in 1993 (EP Fact Sheet 1.6.1999, p.4). In particular, the provision on thirdparty access in the $1992 \mathrm{draft}$ raised concerns with respect to general-interest perspectives. The proposed "common-carrier" principle and the issue of third-party access to the network were interpreted as risks for existing and planned investments in the network, impinging upon 
the safety of supply. The abolition of closed-supply areas was seen as jeopardising the longterm provision of the population, and it was thought that it would lead to considerable price increases for small customers, as captive clients, because the large users would be taken out of the integrated calculations (Schmidt 1998:221). Under pressure from the European-wide public-service debate, the Commission changed its proposal and took into account revised proposals by the Parliament and the Council ${ }^{8}$. However, this proposal did not meet with the support of key actors in the Council either. There, France and Germany, with their opposing positions, blocked the decision-making process.The position of France largely reflects the state's monopoly, i.e., the EDF's position'. The French government was concerned that the EDF public-service model would not survive the liberalisation of the energy sector, this specific model having already been under critical scrutiny in France itself. Yet, the strikes and social movements of 1995 showed that the French still supported their notion of publicservice in principle (Bauby, Boual 1997). However, in basically resisting liberalisation, France saw a two-fold danger: for one, in the absence of a Council policy, the ECJ could rule against the French import and export monopoly; secondly, under its competition law prerogative in Art. 86.3 (90.3), the Commission could liberalise by issuing a directive by-passing the Council. In this situation the French government proposed the single-buyer model, which offered the best possibility for maintaining the existing practice (Schmidt 1998; Eising 2000).

Germany was also opposed to the Commission proposals. However, having closely observed Britain's energy reform, building on expertise provided by an independent Commission, as well as being encouraged by the liberalisation policy of the Federal Cartel Office, the Ministry of Economics gradually changed its view and proposed the liberalisation of the energy sector. This met with a very mixed political response in the domestic arena (Schmidt 1998). The local utilities and their associations opposed liberalisation, while the regional and large utilities opted for the introduction of competition. It was the municipal firms that voiced particular concern over public interests because - according to the argument - the prices for captive consumers would rise; this political concern was taken up by some ministries and the Social-Democratic/Green majority in the Federal Council. By supporting

8 In addition to the licensing procedure for establishing new generation and transmission capacity, the Commission provided for a process of public tendering - merely separate accounting for the vertically integrated companies, instead of an organizational separation of management and operation - and the possibility of negotiated access for third parties (Schmidt 1998:233). The latter saw this as an opportunity to undermine the municipalities' control over local supply areas, a reform which could never be realized solely by domestic political means.

9 In the 80s France had pressed for European liberalization in order to be able to export its surplus electricity. When it realized the full-blown implications of such a step, i.e., the need to subject itself to European competition policy and the consequences that would imply for the domestic monopoly position of EDF, it restricted itself to calling for the closer co-operation between the utilities providers. However, in view of the on-going liberalisation pressure, it could not retreat entirely from its earlier position. In some government quarters (the Finance Ministry), though, the European liberalisation policy was also viewed as an opportunity 
the negotiated third-party access model, based on associative self-regulation, the government circumvented the Federal Council. Since the French and German governments had decided not to let each other be outvoted on the issue of electricity liberalisation, their opposing views made agreement in the Council difficult (Schmidt 1998). However, once they had struck a deal, each under the respective pressure described above, a compromise providing for a complicated market-opening formula was found (Schmidt 1998:250; Eising 2000) and was passed unanimously in the Council in 1996.

By mandating third-party access to the electricity networks and by ending the monopoly rights for the construction of power lines and power stations, Community directive 96/92/EC stipulates that markets be incrementally and moderately opened to competition. It requires member states to ensure that the management (and distribution) of their transmission system is unbundled, in order to prevent discrimination against new competitors. However, member states are free to choose between different forms of unbundling. In some countries a separate legal entity has been created to manage the network and grant access rights, while in other national systems the transmission system operators are only entities which are independent in terms of management and accounting from the generation and supply segments within a single electricity company (Eberlein 1999:18). As far as third-party access is concerned, there are three modes of achieving non-discriminatory access to electricity: regulated-party access, negotiated-party access and the so-called single-buyer model. Most countries have opted for regulated-third-party access, whereby tariffs for network access and use are fixed by relevant authorities and applied to all users. Germany chose negotiated-third-party access, whereby each user negotiates the terms of access with the system operator (Eberlein 1999:18) ${ }^{10}$.

Art. 3 of the directive also includes a public-service clause that allows the imposition of public-interest obligations on energy companies. This makes it possible for liberalisation to be suspended if it prevents compliance with these tasks. To safeguard the security of supply, as well as its regularity and quality at affordable prices, member states can individually define public-service obligations in the general economic interest, provided that they are objective, transparent and non-discriminatory (Eberlein 1999:20).

Because the directive constituted only a modest step towards liberalisation, the Commission has continued to apply the infringement procedures against the import and

to challenge the EDF's position (Schmidt 1998).

10 As a first stage in substantive policy terms, from February 1999, a national proportion of large users (i.e., those who consume more than $40 \mathrm{GWh} /$ year), corresponding to $26 \%$ of national electricity demand, was opened to competition. From February 2000 the threshold was decreased to include consumers who use more than $20 \mathrm{GWh} /$ year (28\% of national demand) and in 2003 decreased further still to include those who use $9 \mathrm{GWh}$ /year, which opens up $33 \%$ of the market to competition. New generation capacity has been open to competition from the start (Matlary 2000, Schmidt 1998; Eberlein 1999:16). 
export and the transmission and distribution monopolies in order to seek pressure through Treaty Law. The Court rulings on Corbeau and Almelo qualified the notion of general-interest services under Art. 86 (ex 90) for the first time. Subsequent Court rulings confirmed this interpretation. If member states disagree with Art. 86.3 (ex 90.3), the Commission, in turn, has to define the Community interest and show that the member states could reach the same objective with less stringent measures. A private competitor must also show that the existing restrictions impede his activities disproportionately and that the political objectives could be reached with less strict measures (Schmidt 1998:263). These rulings starkly contrast with the Court's behaviour in the 80s and early 90s, when it supported the Commission in its application of Art. 86.3 (ex 90.3), which led to the marginalization of the "peau de chagrin", the concept of public service (Belloubet-Frier 1994:274). The ECJ also redefined its own scope of action and its willingness to be used as a political resource to be exploited by the Commission's liberalisation objectives. It emphasised - particularly in its ruling of 1997 (Almelo) but even earlier - that where no Community policy existed, the Commission should refrain from singling out and attacking individual aspects of a regulatory area. Instead, it invited the Commission to devise an overall solution or to wait for the Council to act accordingly (Edward, Hoskins 1995).

In light of my propositions, we can conclude from the story of electricity liberalisation (Schmidt 1998; Scott 1995; Eising 2000) and its implications for general-interest services that the Commission would indeed have preferred to use Art. 86.3 (ex 90.3), but that it failed to do so because member states opposed this attempt. Member states brought their opposition to bear by exerting influence on Commissioners - despite the formal independence of the latter - whenever crucial member-state interests were at stake (Schmidt 1998:316). What emerges, moreover, is that the structure of the market made it difficult for the Commission to break this resistance by finding alliance partners to launch a liberalisation procedure. It was faced both with a de facto providers' cartel, organised in the European association of UCTPE, and with the fact that large users were bought off by being offered special rates (Schmidt 1998:317). Hence the Commission had to use the market-integration avenue, which had an impact on policy outcomes: the Parliament, which was an important opponent to liberalisation, had to be included; the Commission was thus forced to substantially alter its reform plans in favour of general-interest services (Schmidt 1998:224/225). 


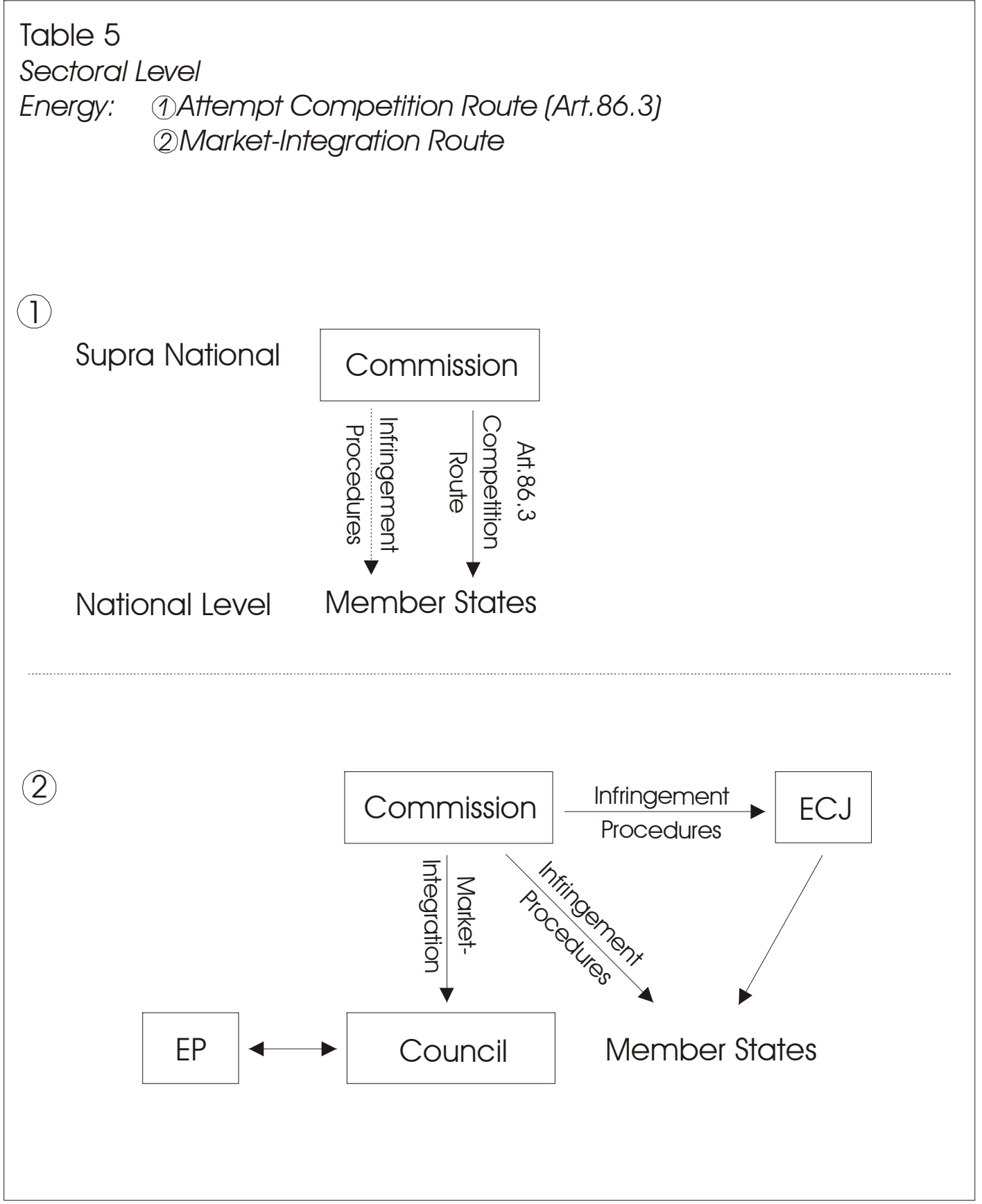

Existing empirical analyses also show that the individual competition instrument (infringement procedure) was skilfully used to promote the willingness of individual member states to support a common policy: faced with the threat of a special infringement procedure against import and export monopolies, the French proposed "their liberalisation model", the singlebuyer model. However - as Susanne Schmidt points out - the Commission had to maintain a delicate balance in its use, on the one hand between the individual-infringement procedures as a lever to create interest in a council policy decision, and on the other the need not to disturb negotiations by using individual procedures once they were under way (Schmidt 1998) ${ }^{11}$.

11 "Sobald die Ratsverhandlungen initiiert waren, hätten parallele wettbewerbsrechtliche Entscheidungen als einseitige Einflußnahme der Kommission gegolten, mit der sie Verhandlungsergebnisse präjudizierte. Mit 
The Court played an important role in favouring general-interest goals in the policy-making process by ruling as it did in the cases of Corbeau and Almelo and is indicating an increasing unwillingness to be the ally of the Commission in pushing liberalisation issues.

\section{3 Transport (Rail)}

One reason for the development of a common railway policy (Kerwer and Teutsch 2001) beyond the general market integration philosophy - was the crisis prevailing in the rail sector. Railways have continuously been losing out in intermodal competition between rail, road haulage and air transport. The aim of the early Community railway policy was to reduce the disadvantages in intermodal competition resulting from state intervention. In a programme to relaunch the railways as a means of transport, a growth strategy was deployed with the Commission new intent on assuming a much more activist role in this process. The core idea has always been to introduce intra-modal competition and technical interoperability and to increase the environmental sustainability of transport, while at the same time investing in a system of high-speed trains at the European level (Kerwer and Teutsch 2001).

The Common Railway Policy of the beginning of the 90s was decided upon relatively quickly, in less than two years. This is all the more surprising in view of the factual decisionmaking process, for although it is possible to use the Qualified Majority Rule under the terms of the Single European Act, in the Transport Council the principle of unanimity is still in force whenever a member state sees unfavourable consequences for regional development and the operation of their transport systems. The pressure to find a consensus is thus particularly great in transport policy making. As mentioned, the Commission, supported by the Court and the Parliament, which emphasised the importance of railway networks in its resolution of 1990, promoted the creation of a single market in transport, while the Council in its majority resisted these policy initiatives. With respect to member state governments, two coalitions could be distinguished: on the one hand, Britain and the Netherlands were unconditional supporters of liberalisation; on the other, there were conditional supporters of a railway liberalisation who saw problems of technical compatibility and operational security. France was the most sceptical and sought to slow down liberalisation as much as possible ${ }^{12}$. It supported the idea of greater co-operation between different (national) railway enterprises. In

ihrer Rolle als unabhängiger Agendagestalter war dies nicht zu vereinbaren" (Schmidt 1998:321).

12 At closer scrutiny, though, it emerges that it played a multi-level game with divided roles: while officials in the Ministry of Economics sought to advance the domestic process of liberalisation by co-operating with the Commission, politicians - influenced by the strikes and social movements - articulated their support for 
spite of the opposition, the reform of 1991 was passed in a relatively short time firstly because the political impetus of the Single Market Programme was skilfully used by the pro-liberalizers. Secondly, instead of emphasising that railways were a part of the infrastructure, as had been done previously, the programme for relaunching the railways as a growth industry changed decision-makers' way of thinking about railways; and the general sense of crisis regarding the railways increased the willingness to experiment with reforms. Thirdly, the directive did not entail precise and demanding prescriptions, but rather modest requirements (Kerwer and Teutsch 2001). The new regulatory principles adopted entail the abolition of government intervention in railway management and replacing it with private-enterprise objectives. Railways are no longer exempt from rules on state subsidy. Any state aid granted has to obtain authorisation from the Commission. However, this does not apply to compensation for public-service obligations or for exceptional social costs (such as pension funds). Infrastructure management and service operation have to be separated at the level of accounting (as opposed to the organisational and - more demandingly - the institutional level). The mandatory liberalisation of market access is only related to international undertakings and combined transport.

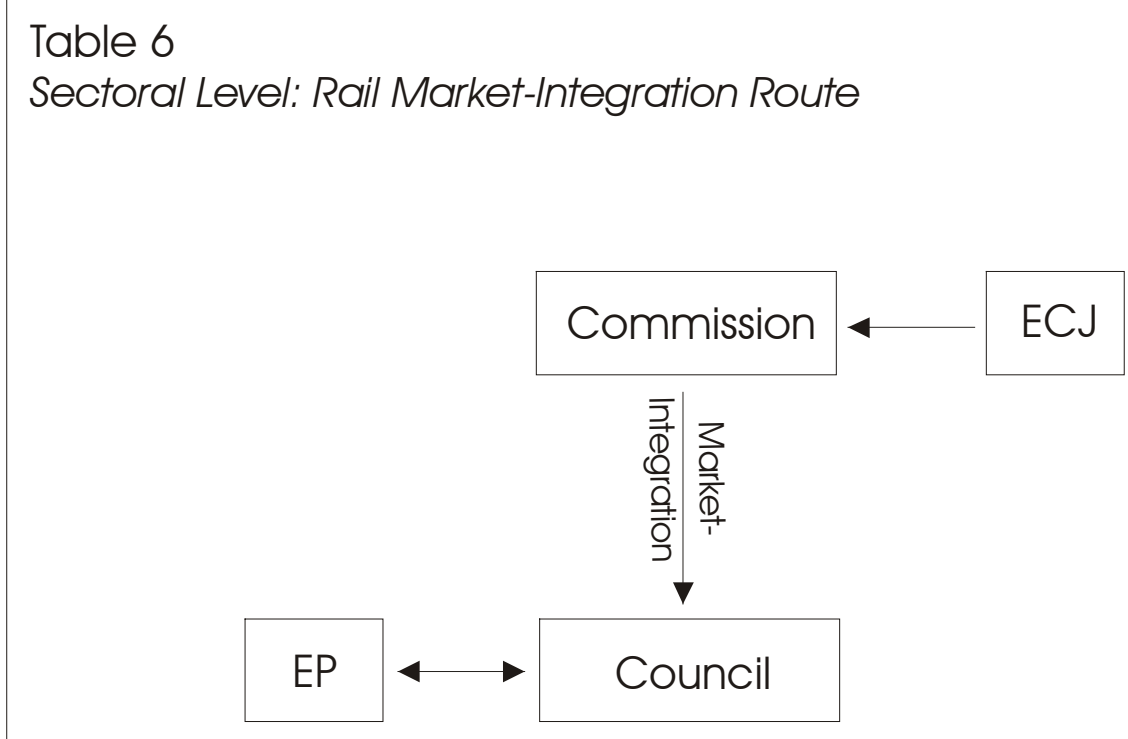

The most recent European drafts on rail regulations of 1999/2000 seek to enhance competition while at the same time allowing for the pursuit of general-interest goals: The amended "licensing directive" (1995/18EC) wants to ensure the fair, transparent and nondiscriminatory treatment of all railway undertakings in the licensing process. The issuing of licensing shall be carried out by a body which does not provide rail transport services itself. As regards general-interest services, the directive also provides that a railway undertaking shall 
comply with national law and regulatory provisions related to technical regulation requirements, to health and safety as well as to the protection of consumers' benefits (Official Journal of the European Communities, p. C178/23). The new "infrastructure capacity directive" wants to ensure that the allocation of charges for capacity and railway infrastructure follow competitive principles. It also provides for member states to establish a regulatory body independent of the infrastructural undertakings. In the decision-making process the EP, while emphatically supporting rail network liberalisation (FAZ 15.8.2000), called for more investment in infrastructure and transport technology in order to make up for lost ground vis à vis road transport. In the legislative resolution on the Council's common position on the second directive, the EP's Committee on Regions, Transport and Tourism voted to add a paragraph in favour of public-benefit transport systems. Member states should be allowed to take the necessary measures to ensure that priority is given to public-benefit transport services by providing "the railway operators with compensation for financial losses arising from the fact that a certain rail capacity must be allocated in the interests of public transport service" (Art. 14, paragraph 1a) $)^{13}$.

In the light of our general claims, this decision-making process in rail-liberalisation and its outcomes show, firstly, that attributing exclusively pro-competition preferences to the Commission is in part wrong, since the Commission has not only promoted liberalisation, but has also supported an investment programme to relaunch the railways. Further it shows that the European Parliament has been supportive of efforts to incorporate public-service interests, and as in the cross-sectoral arena, France has been particularly active in forging an alliance with the EP in order to promote general-interest services in the course of liberalisation. However, it also shows that the EP is a supporter of liberalisation in the rail sector in order to strengthen rail transport vis à vis the other modes of transport.

\section{Conclusion}

I started out with the question: Why is it that - contrary to the claim about the in-built bias of European policies in favour of competition - empirically we are faced with decision-making outcomes in the utilities which are enhancing public interest goals? The prevalence of

13 The Commission also proposed a draft regulation on a mandatory European wide bidding process for publictransport licenses in order to introduce competition into this sector of transport and to prevent crosssubsidizing. However, it also provides for multiple exemptions from competitive bidding: e.g., for small undertakings or small communes, for lines with a minor need for subsidies ( $20 \%$ of turnover) or for safety and environmental reasons. In order to prevent "raisin" picking, both profitable line and those operating at a loss can be put up for bidding in one package (Die Welt, 12.7.2000). 
competition and market integration goals has been traced to the low consensus costs linked to decision-making in competition policy. The Commission can initiate infringement procedures which may or may not be supported by the ECJ. The Commission can also issue directives to force special undertakings to comply with rules of competition without passing through the Council and the EP. So, indeed, using these avenues of decision making involves lower decision-making costs, and it would be completely rational if the Commission would primarily use these avenues when initiating policy in the utilities. How can countervailing empirical tendencies, then, be accounted for? It is claimed and shown that - since the Commission is not the sole policy initiator - such measures may be launched by individual member states that, in view of domestic pressure, play a multi-level and multi-arena game. They not only bring the issue of concern (for a minority) to the European level, they also shift it from the sectoral to the intergovernmental arena in order to increase their leverage in influencing decision-making. This process can be empirically observed in the case of cross-sectoral policymaking in favour of public services that was initiated by France and resulted in the insertion of general economic interest goals into the Amsterdam Treaty. The process was facilitated by forming an alliance with the EP, an actor pre-dominantly favouring general interest goals.

Having the EP as a coalition partner proves to be beneficial to advancing general interest services in individual sectors as well. Hence choosing a decision-making avenue that gives the $\mathrm{EP}$ an important role clearly increases the chances of bringing such a decision about. This is borne out by the evidence in all three sectors, even in telecommunications, where the competition decision-making route - under Art 86.3 (ex 90.3) - was the predominant avenue in the 90s, when it was frequently used to bring liberalisation about and - in spite of the opposition of member states on institutional grounds - was confirmed by the ECJ. Simultaneously, the Commission skilfully used individual infringement procedures to increase the willingness of individual member states to politically support a European liberalisation process at the Council level. For once a country was forced to liberalise, it developed a general interest that the other member states follow suit.

The use of the competition decision-making avenue by the Commission proved to be much more difficult in the area of energy liberalisation. Here- in contrast to telecommunications - member-states mustered up institutional and substantive opposition to the Commission's use of Art 86.3 (ex 90.3). Individual infringement procedures could not be easily utilised to break-up the anti-liberalisation front of member states. The EC's rulings played an important role in this context. They expressed a less stringent view on public monopolies, and they sent a signal to the Commission to use the route of political decisionmaking. Hence the market-integration avenue was used, implicating the Council and the EP. 
This made the decision process slow and cumbersome and its outcome diverse. Different institutional solutions were allowed for, and general interest services were incorporated.

The development in the rail sector also calls into question the proposition that there is an inherent bias due to the prevalence of the competition route, but it does so from a different angle. Here the Commission's preferences are not uniquely in favour of liberalisation in the first place, but show a double orientation: they are at the same time oriented towards largescale investment projects in the railways to strengthen their position in intermodal competition. Simultaneously, the preferences of the EP are not uniquely in favour of generalinterest goals either; they are also pro-liberalisation. This is due to the fact that the support of the railways as such (as opposed to road and air traffic) is considered to be general-interest oriented because of being an environmentally-friendly decision. In rail the Commission did not use the competition route in decision-making. One reason may be that the technical feasibility of market integration is more difficult to achieve here than in energy and telecommunications. Large-scale investment projects in the railways also required positive decisions in the Council. Due to the deep institutionalisation of the national railway systems and the high consensus needs of the decision path chosen, the European decision-making outcome left a lot of leeway for discretion at the national level, including the possibility to continue pursuing public-interest goals in the liberalised railways.

In conclusion then, the case of policy making in favour of general-interest goals at a crosssectoral level and in individual utilities shows that there is indeed a strong tendency in European policy making in favour of competition and market integration. This is because, when the competition route is chosen, the costs needed for consensus building are saved. However, there are several mechanisms and factors that work against this tendency, serving to break its force to some extent: the dynamism of cross-arena policy making that may increase the lever for bargaining, even for minority positions; the increasingly important role the European Parliament plays in defending the interests of its constituents; the resistance of member states to the Commission's use of the competition route under Art. 86.3 (ex 90.3); the fact that, from the outset, the Commission may not always have pro-competition preferences, but market-correcting ones instead; and finally, the time dimension, which points to the fact that liberalisation occurs in stages, that there is an initial phase of market creation, and that the abolishment of monopolies is followed by a stage of re-regulation in which the need to correct the negative effects of liberalisation is perceived. 


\section{References}

Bauby, P. and Boual, J.-C., (eds.) Les services publics au défi de l'Europe. Paris: Editions Ouvrières, 1993.

Bauby, P. and Boual, J.-C. "La prise en compte de la notion de „service public“ dans la construction européenne." In P. Warin (ed.) Quelle Modernisation des Services Publics? Paris: La Découverte, 1997: 309-332.

Bauby, P., Boual, J.-C. Pour une Citoyenneté Européenne: Quels Services Publics? Paris: Editions de l'Atelier / Editions Ouvrières, 1994.

Baumol, W.J., Panzar, J.C., Willig, R.D. Contestable Markets and the Theory of Industry Structure. San Diego et al: Harcourt Brace Jovanovich, 1988.

Belloubet-Frier, N. "Service Public et Droit Communitaire" Actualité Juridique - Droit Administratif 1994 (4): 270-285.

Bergman, L. et al. Europe's network industries. Conflicting priorities. Telecommunications, London: Centre for European Policy Research, 1998.

Douillet, A.-C. and Lehmkuhl, D. "Strengthening the Opposition and Pushing Change: The Paradoxical Impact of Europe on the Reform of French Transport." In A. Héritier et al., Differential Europe: New Restrictions and Opportunities for Policy-Making in Member States. Rowman \& Littlefield Publishers, 2001.

Dury, R. Services publics - "Services d'intérêt général et onférence intergouvernementale", Parlement européen, Bruxelles, Seminaire du 26 février 1996.

Eberlein 1999 (Grande, E. and Eberlein, B. Der Aufstieg des Regulierungsstaates. Zur Transformation der politischen Ökonomie der Bundesrepublik Deutschland. Presentation March 1999 at the Max Planck Project Group: Law, Politics and Economics, Bonn, 1999.)

Edward, D. and Hoskins, M. "Deregulation and EC Law. Reflections arising from the XVI Fide Conference" Common Market Law Review, 32 (1) 1995: 157-186.

Eising, R. Liberalisierung und Europäisierung: die regulative Reform der Elektriqitätsversorgung in Großbritannien, der Europäischen Gemeinschaft und der Bundesrepublik Deutschland. Leske + Budrich, 2000.

Engel, Chr., Knieps, G. Die Vorschriften des Telekommunikationsgesetzes über den Zugang zu wesentlichen Leistungen. Nomos, Baden-Baden, 1998.

European Commission Communication from the Commission: Services of General Interest in Europe. Luxembourg: Office for Official Publications of the European Communities, 1996.

Forsthoff, E. "Verfassungsprobleme des Sozialstaats." In E. Forsthoff (ed.) Rechtsstaatlichkeit und Sozialstaatlichkeit. Wissenschaftliche Buchgesellschaft, Darmstadt 1968: 145-164.

Hart, T. "A Dynamic Universal Service for a Heterogenous Union." Tele-communications Policy 22 (10) 1998: 839-852.

Héritier, A. and Schmidt S. "After Liberalisation: Public Interest Services and Employment in the Utilities." In F.W. Scharpf and V.A. Schmidt (eds.) Welfare and Work in the Open Economy, Volume II. Divrse Responses to Common Challanges, Oxford: Oxford University Press, 2000. 
Judge et. al., "Ripples or Waves: The European Parliament in the European Community Policy Process" Journal of European Public Policy, 1994: 27-52.

Kerwer, D., Teutsch, M. "The Dynamics of the EC Common Transport Policy. " In A. Héritier et al., Differential Europe: New Restrictions and Opportunities for Policy-Making in Member States, Rowman \& Littlefield Publishers, 2001.

Le Nestour, Zinow, C. "Rechtsfragen des Service Public." In Recht der Energiewirtschaft. 55 (4) 1994, 129-144 and 55 (5) 1994, 170-174.

Mandil Report, zitiert nach S. Schmidt, Liberalisierung in Europa: Die Rolle der Europäischen Kommission, 1994.

Matlary, J. H. "Energy Policy: From a National to a European Framework?" In: H. Wallce, W. Wallace (eds.) Policy-making in the European Union. Oxford: Oxford University Press, 2000: 257-277.

Mayntz, R., Scharpf, F.W. "Der Ansatz des akteurzentrierten Institutionalismus." In R. Mayntz, F.W. Scharpf (eds.) Gesellschaftliche Selbstregelung und Politische Steuerung. Frankfurt am Main: Campus 1995: 39-72.

McGowan F., Wallace, H. "Towards a European Regulatory State." Journal of European Public Policy 1996 (3): 560 - 576.

McGowan, F. (ed.) European energy policies in a changing environment. Heidelberg: Physica-Verlag, 1996.

Prosser, T. "Theorising Utility Regulation." Modern Law Review 1999: 196-217.

Scharpf, F.W. Governing in Europe: Effective and Democratic? Oxford / New York: Oxford University Press, 1999.

Schmidt, S.K. Liberalisierung in Europa: Die Rolle der Europäischen Kommission. Frankfurt am Main: Campus, 1998.

Scott, C. "Changing Patterns of European Community Utilities Law and Policy: An Institutional Hypothesis." In J. Shaw, G. More (eds.) New legal Dynamics of European Union. Oxford: Clarendon Press, 1995: 193-215.

Thatcher, M. The Europeanisation of Regulation. The Case of Telecommunications. European University Institute, Florenz, Working Paper RSC No 99/22, 1999. 